\title{
Small mammals of Kampinos National Park and its protection zone, as revealed by analyses of the diet of tawny owls Strix aluco Linnaeus, $1758^{(*)}$
}

\author{
Grzegorz LESIŃsKI $^{1}$, Jerzy RoMANOWSKI ${ }^{2}$, Jakub GRYZ $^{3}$, Adam OLSZEWSKI ${ }^{4}$, Marek \\ Kowalski ${ }^{5}$, Dagny KraUzE-Gryz ${ }^{6}$, Bogumila Olech ${ }^{7}$, Danuta PePlowsKa-MarCZAK ${ }^{4}$, \\ Adam TARLOWSKI ${ }^{5}$

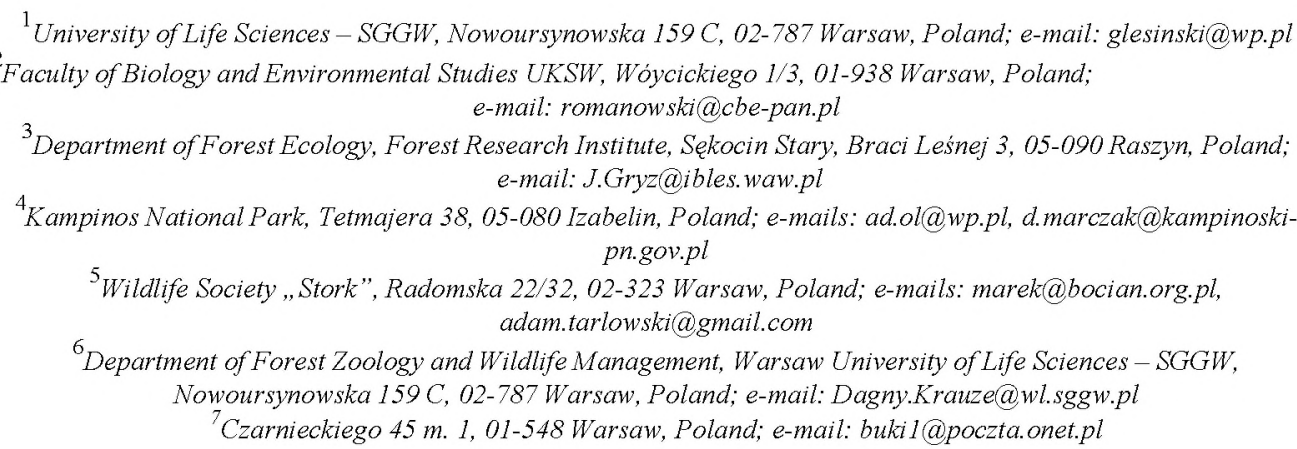

\begin{abstract}
Analyses of tawny owl pellets were used to determine the species composition and distribution of small mammals in Kampinos National Park and its protection zone (central Poland). The total material collected from 58 localities contained the remains of 11,235 vertebrates (including 8,335 mammals). The study revealed 29 species of small mammals of the following orders: Soricomorpha -4 , Chiroptera -9 , Rodentia -14 , Lagomorpha -1 and Carnivora - 1. These included two bat species of special interest (Myotis myotis and Barbastella barbastellus) listed in the 2nd Annex to the Habitats Directive of the European Union. Muscardinus avellanarius, a rodent typical of broadleaved woodland, appeared to be relatively common and abundant in suitable habitats. Species inhabiting wet habitats, Microtus oeconomus and Neomys fodiens, were found in many localities, whereas Arvicola amphibius was rarer and less abundant. Some important refuges of small mammals were found, mostly in strictly protected areas. Although the studies conducted to date in this area likely reveal a complete list of small species of Soricomorpha and Rodentia, it is possible that 3-5 species of Chiroptera and 2 small species of Carnivora may remain to be identified.
\end{abstract}

Key words: Soricomorpha, Chiroptera, Rodentia, Lagomorpha, Carnivora, pellet analysis, tawny owl, central Poland

\section{INTRODUCTION}

Kampinos National Park with its protected zone is situated close to a large scientific centre, Warsaw, and has been an area of intensive zoological study for some decades, with many studies focussing on the small mammals of the area. Studies on bats conducted in the late 1980s and early 1990s revealed the presence of 12 species (Kowalski \& Lesinski 1995), and three species were subsequently discovered (Lesiński 2003, Lesinski et al. 2011). Although the communities of small ground-dwelling mammals have largely been identified through ecological studies based on live trapping (Andrzejewski et al. 1978, Adamczyk et al. 1988, Lesiński et al. 1990, Łopucki et al. 2007), a substantial amount of information on the species

\footnotetext{
${ }^{(*)}$ This paper is dedicated to the memory of the late Prof. dr hab. Jacek Goszczyński and the late Dr Andrzej Lech Ruprecht, two outstanding zoologists who taught us methods for the ecological study of mammals and birds.
} 
composition of small mammals has been presented by Romanowski (1988), Goszczyński et al. (1993), Żmihorski (2005), Romanowski \& Żmihorski (2006, 2008, 2009) and Lesiński \& Gryz (2012) as a result of owl pellet analyses. Andrzejewski (2003) and Danylow et al. (2012) summarised data regarding this group from Kampinos National Park. Thus far, one species of Erinaceomorpha, four species of Soricomorpha and 13 species of Rodentia have been reported.

Regardless, there remains too little information about the distribution of each species and their main refuges in this area and the structure of their communities in various habitats. Indeed, some areas remain under high anthropogenic pressure, which should strongly influence the structure of small mammal communities. The aim of this study was to obtain data on localities of small mammals in the Park and its protection zone. Taking into account that many parts of the area are highly transformed by human activity, we attempted to assess how this pressure affects the occurrence of small mammals.

\section{STUDY AREA, MATERIAL AND METHODS}

The study was conducted in the Kampinos Forest near Warsaw in central Poland (Fig. 1). A large part of this area $(38,548 \mathrm{ha})$ is protected as a national park that was established in 1959 to preserve a landscape in which two broad latitudinal belts of dunes covered by forest are separated by open wetlands. The forest cover of Kampinos National Park is approx. $73 \%$. The Park lies in the Vistula River basin, and its waterway network is substantially transformed anthropogenically; no vast, natural water bodies are present. In some places, permanent water bodies derived from underground water are present, and there are also hollows with stagnant water in the complex of belts of dunes and system of inter-dune cavities. The large open and forested areas are periodically flooded in March/April; long-term droughts occur in summer when the water flow is at its lowest (Andrzejewska et al. 2012). The dunes are covered mostly by pure and mixed coniferous forest; broad-leaved forests and alder forests occur in the lower parts and in swamps. The most numerous tree species covering the dunes are Scots pine Pinus sylvestris Linnaeus, 1753 and oaks Quercus spp., birches Betula spp. and black alder Alnus glutinosa (Linnaeus, 1753) also play an important role in tree stands. The open areas are mostly meadows, including wet and marshy meadows and sedge-dominated wetlands but also xerothermic grasslands and other dune plant communities. A total of 151 plant communities have been recorded in the Park, with a prevalence of forest and shrubland (Andrzejewska et al. 2010).

In the protection zone are mostly cultivated fields and human settlements. The northern and eastern borders of the study area are delineated by the Vistula River, with its valley covered mostly by meadows or riparian forests. The western border lies on the Bzura River. In the south, the study area is bordered by the road between Warsaw and Sochaczew (Fig. 1).

The pellets of tawny owls Strix aluco Linnaeus, 1758 were collected in 58 localities (Fig. 1) between 1980-2012 from under trees that were used as breeding or roosting sites (40), boxes for tawny owls (12) and abandoned residential buildings or barns (6). The total number of vertebrate prey items was 11,235 (mammalian prey accounted for 8,335 individuals).

A standard method of pellet analysis was used. The material was rinsed with water, and the identified bone elements were collected, mostly consisting of skulls and mandibles but also humerus bones for moles Talpa europaea Linnaeus, 1758. We used the keys of Pucek (1984) and Ruprecht (1987) to determine the species. A reference collection of skulls helped to confirm the preliminary determination, which was particularly useful in the case of bats.

The localities were usually named with regard to the neighbouring villages; a range or forest district with compartment number were used for sites located in the forest interior. In the latter case, the names of forest divisions were abbreviated (KA - Kampinos, KR - Kromnów, LA - Laski). 


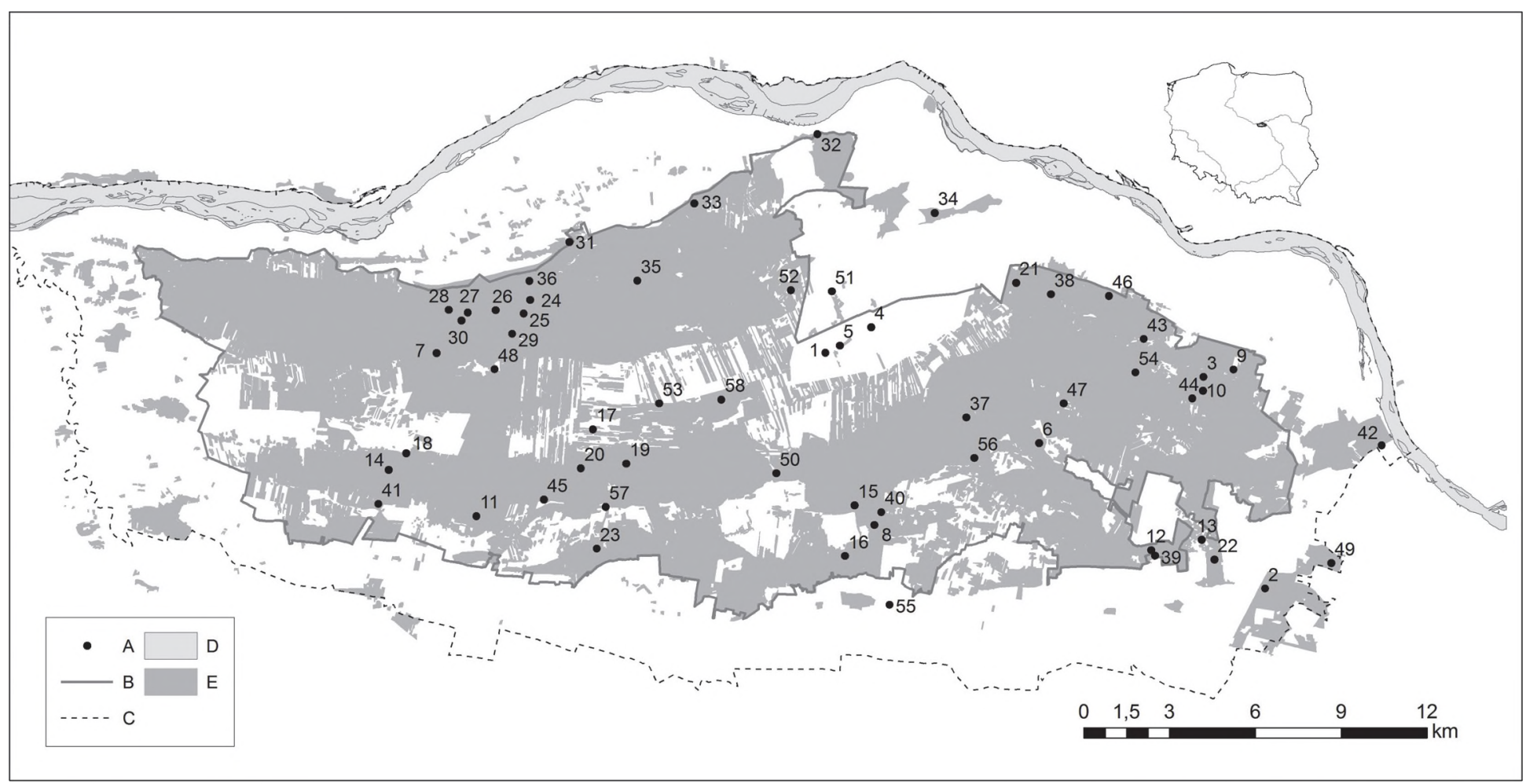

Fig. 1. Study area indicating sites of pellet collection. A - study sites: 1 - Aleksandrów, 2 - Bemowo, 3 - Bialy Grąd, 4 - Brzozówka E, 5 - Brzozówka N, 6 - Cyganka, 7 Dąb Kobendzy, 8 - Debły, 9 - Dziekanów Leśny, 10 - Grabowy Grąd, 11 - Granica, 12 - Hornówek, 13 - Izabelin, 14 - KA 101, 15 - KA 240, 16 - 251, 17 - KA 294, 18 KA 66, 19 - KA 79, 20 - KA 83, 21 - Kaliszki, 22 - Klaudyn, 23 - Korfowe, 24 - KR 103, 25 - KR 104, 26 - KR 106, 27 - KR 108, 28 - KR 110, 29 - KR 156, 30 - KR 160, 31 - KR 20, 32 - KR 217, 33 - KR 4, 34 - KR 400, 35 - KR 48, 36 - KR 56, 37 - LA 154, 38 - LA 24, 39 - Lipków, 40 - Lawy, 41 - Lazy Leśne, 42 - Młociny Park, 43 Mhynisko, 44 - Na Miny, 45 - Nart, 46 - Palmiry Lomna, 47 - Pociecha, 48 - Posada Demboskie, 49 - Radiowo, 50 - Roztoka, 51 - Sowia Wola, 52 - Sowia Wola Folwarczna, 53 - Stara Dąbrowa, 54 - Wywrotnia Góra, 55 - Zaborów, 56 - Zaborów Leśny, 57 - Zamczysko, 58 - Żurawiowe, B - borders of Kampinos National Park, C borders of the study area, D - Vistula river, E - forests. 


\section{RESULTS}

In this study, we confirmed the presence of 29 species belonging to five orders: Soricomorpha (4 species), Chiroptera (9), Rodentia (14), Lagomorpha (1) and Carnivora (1). The first date of pellet collection, with the respective number of individuals (in brackets), is presented in the list of localities.

Soricomorpha

\section{Mole - Talpa europaea Linnaeus, 1758}

21 localities: Cyganka: 12 III 2012 (1), Grabowy Grą: 20 I 1982 (1), Izabelin: 2 V 2012 (1), KA 66: 10 II 2000 (1), KA 83: IV 2003 (1), Kaliszki: 18 VII 1984 (1), Korfowe: 12 VII 1999 (1), KR 103: 17 IX 2009 (1), KR 106: 23 IV 2009 (1), KR 108: 4 V 2011 (2), KR 156: 26 IV 2012 (1), Lipków: 26 IV 1982 (1), Ławy: 5 IV 2012 (1), Młociny Park: 25 V 1983 (7), Młynisko: 25 V 1983 (1). Na Miny: 3 X 2011 (7), Posada Demboskie: 31 III 2000 (2), Roztoka: 10 I 2012 (1), Sowia Wola Folwarczna: 27 VI 1996 (1), Wywrotnia Góra: III 2003 (1), Zaborów Leśny: 27 V $1995(10)$.

\section{Common shrew - Sorex araneus Linnaeus, 1758}

37 localities: Aleksandrów: VI 2008 (8), Biały Grad: 12 V 1983 (3), Brzozówka E: X 2006 (1), Brzozówka N: 10 III 2012 (1), Cyganka: 12 III 2012 (44), Dąb Kobendzy: 19 IV 1983 (14), Dziekanów Leśny: 23 III 1982 (4), Grabowy Grad: 22 VI 1982 (46), Granica: VII 2004 (1), Izabelin: 2 V 2012 (23), KA 66: 10 II 2000 (4), KA 83: IV 2003 (4), Kaliszki: 18 VII 1984 (16), Korfowe: 12 VII 1999 (16), KR 20: 6 X 2011 (15), KR 56: 6 X 2011 (30), KR 103: 26 IV 2008 (2), KR 104: 23 IV 2009 (1), KR 106: 19 III 2008 (1), KR 108: 4 V 2011 (5), KR 110: 26 IV 2012 (7), KR 156: 23 IV 2009 (5), KR 160: 17 IX 2009 (1), KR 217: 19 V 2010 (1), KR 400: 7 V 2010 (1), LA 154: 25 IV 1993 (8), Lazy Leśne: 11 IV 2012 (8), Mlociny Park: 25 V 1983 (7), Mlynisko: 25 V 1983 (16), Na Miny: 3 X 2011 (146), Nart: 2 III 1984 (1), Palmiry-Łomna: 18 VII 1984 (2), Posada Demboskie: 4 VIII 1989 (4), Roztoka: 10 I 2012 (37), Sowia Wola Folwarczna: 27 VI 1996 (66), Wywrotnia Góra: 18 X 1994 (5), Zaborów Leśny: 13 VIII 1980 (1).

\section{Lesser shrew - Sorex minutus Linnaeus, 1766}

32 localities: Brzozówka N: 10 III 2012 (1), Cyganka: 12 III 2012 (12), Dąb Kobendzy: 19 IV 1983 (8), Dziekanów Leśny: 20 II 1984 (2), Grabowy Grąd: 22 VI 1982 (26), Granica: VII 2004 (1), Izabelin: 2 V 2012 (1), KA 83: XI 2004 (1), KA240: 10 III 1999 (1), Kaliszki: 18 VII 1984 (2), Korfowe: 12 VII 1999 (6), KR 20: 6 X 2011 (1), KR 56: 6 X 2011 (10), KR 103: 26 IV 2008 (3), KR 104: 26 IV 2008 (1), KR 106: 19 III 2008 (2), KR 108: 4 V 2011 (2), KR 110: 26 IV 2012 (7), KR 156: 23 IV 2009 (4), KR 160: 4 V 2011 (1), LA 154: 25 IV 1993 (2), Lipków: 26 IV 1982 (2), Łazy Leśne: 11 IV 2012 (1), Mlociny Park: 12 IV 2008 (1), Mlynisko: 25 V 1983 (14), Na Miny: 3 X 2011 (24), Nart: 2 III 1984 (3), Posada Demboskie: 4 VIII 1989 (1), Roztoka: 10 I 2012 (4), Sowia Wola Folwarczna: 27 VI 1996 (25), Wywrotnia Góra: 18 X 1994 (1), Zaborów Leśny: 27 V 1995 (2).

\section{European water shrew - Neomys fodiens (Pennant, 1771)}

20 localities: Brzozówka N: 10 III 2012 (2), Cyganka: 12 III 2012 (2), Dąb Kobendzy: 16 III 2012 (30), Dziekanów Leśny: 23 III 1982 (3), Grabowy Grą: 22 VI 1982 (68), KA 66: 10 II 2000 (3), Kaliszki: 8 XI 2011 (1), Korfowe: 12 VII 1999 (1), KR 103: 26 IV 2008 (1), KR 106: 4 V 2011 (2), KR 156: 4 V 2011 (1), Łazy Leśne: 11 IV 2012 (4), Młociny Park: 22 II 1984 (1), Mlynisko: 25 V 1983 (36), Na Miny: 3 X 2011 (4), Pociecha: 7 III 2012 (1), Posada Demboskie: 31 III 2000 (1), Roztoka: 10 I 2012 (3), Zaborów Leśny: 27 V 1995 (3), Zamczysko: 16 IV 2012 (4). 
In the food of owls Sorex araneus was the most common and abundant within the order Soricomorpha. The remaining three species from this group were not frequently captured by owls, though Sorex minutus was relatively common. Neomys fodiens occurred in various parts of Kampinos Forest (Fig. 2) but showed a high contribution to small mammal communities only in a few localities. $N$. fodiens was particularly abundant in the wet habitats of "Sieraków", a strictly protected area: Mlynisko $-31.1 \%$ of mammalian prey $(\mathrm{N}=135)$, Grabowy Grad $25.7 \%(\mathrm{~N}=448)$ and $\mathrm{Na}$ Miny $-12.5 \%(\mathrm{~N}=1,349)$.

Chiroptera

Large mouse-eared bat - Myotis myotis (Borkhausen, 1797)

1 locality: KR 156: 17 IX 2009 (1).

Natterer's bat - Myotis nattereri (Kuhl, 1817)

2 localities: Dziekanów Leśny: 22 VI 2011 (1), Roztoka: 3 IV 2012 (1).

Brandt's bat - Myotis brandtii (Eversmann, 1845)

1 locality: Sowia Wola Folwarczna: 27 VI 1996 (1).

Parti-coloured bat - Vespertilio murinus Linnaeus, 1758

2 localities: Roztoka: 10 I 2012 (1), Sowia Wola Folwarczna: 15 IV 1997 (1).

Serotine bat - Eptesicus serotinus (Schreber, 1774)

3 localities: KR 104: 4 V 2011 (1), Posada Demboskie: 4 VIII 1989 (1), Sowia Wola Folwarczna: $30 \mathrm{~V} 2005$ (7).

Noctule bat - Nyctalus noctula (Schreber, 1774)

8 localities: Izabelin: 7 VIII 2012 (1), Kaliszki: 8 XI 2011 (1), KR 103: 17 IX 2009 (1), KR 156: 26 IV 2012 (1), KR 400: 7 V 2010 (1), Mlociny Park: 28 III 2008 (1), Mlynisko: 8 IX 1984 (1), Sowia Wola Folwarczna: 23 VI 2000 (1).

Nathusius' pipistrelle - Pipistrellus nathusii (Keyserling \& Blasius, 1839)

2 localities: Mlociny Park: 23 VII 2009 (1), Na Miny: 10 X 2012 (1).

Brown long-eared bat - Plecotus auritus (Linnaeus, 1758)

5 localities: Dziekanów Leśny: 20 VI 2000 (1), Mlociny Park: 9 IV 2010 (1), Posada Demboskie: 12 X 1995 (1), Roztoka: 10 I 2012 (1), Sowia Wola Folwarczna: 27 VI 1996 (1).

Barbastelle bat - Barbastella barbastellus (Schreber, 1774)

3 localities: Kaliszki: 8 XI 2011 (1), KR 156: 4 V 2011 (1), Sowia Wola Folwarczna: 15 IV 1997 (1).

Bats were represented by 62 individuals belonging to 9 species. The commonly captured Nyctalus noctula and Plecotus auritus were found in different parts of the study area. Eptesicus serotimus and Barbastella barbastellus occurred in three localities. Vespertilio murinus was discovered in the western part, while Pipistrellus nathusii in the eastern part of Kampinos Forest. The remaining species were found in only a few localities. 


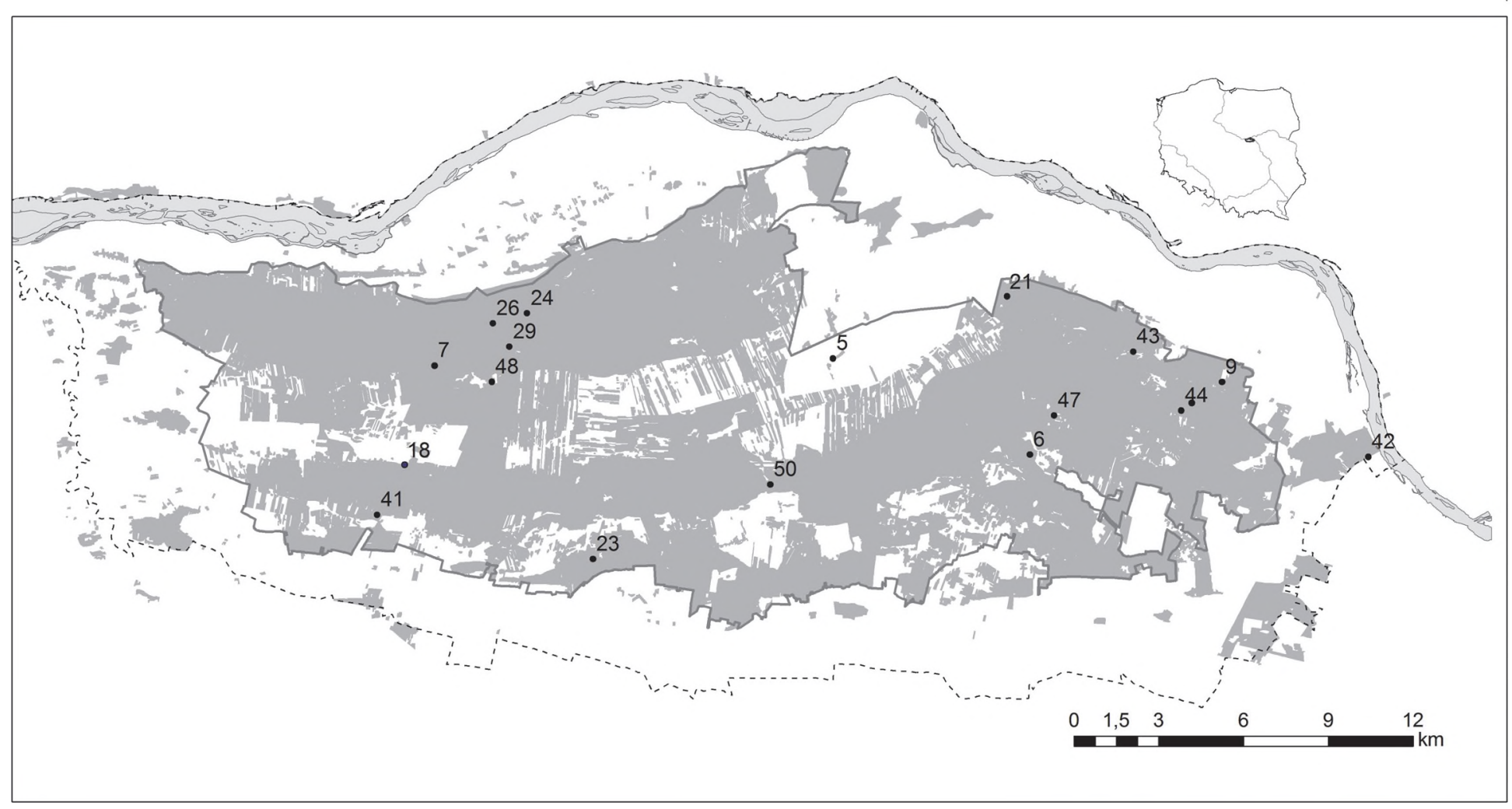

Fig. 2. Localities of Neomys fodiens in the study area. For explanations see Fig. 1. 
Rodentia

\section{Bank vole - Myodes glareolus (Schreber, 1780)}

48 localities: Bemowo: 9 X 1998 (3), Biały Grąd: 12 V 1983 (2), Brzozówka E: X 2006 (1), Brzozówka N: 1 V 2012 (1), Cyganka: 12 III 2012 (16), Dąb Kobendzy: 19 IV 1983 (3), Debły: 1 VII 2011 (1), Dziekanów Leśny: 23 III 1982 (4), Grabowy Grąd: 22 VI 1982 (5), Izabelin: 2 V 2012 (3), KA 66: 10 II 2000 (25), KA 83: IV 2003 (15), KA 101: 16 III 1995 (2), KA 240: 10 III 1999 (8), KA 251: 10 III 1983 (4), Kaliszki: 18 VII 1984 (4), Klaudyn: 12 X 2011 (1), Korfowe: 12 VII 1999 (98), KR 20: 6 X 2011 (3), KR 48: 22 III 1991 (7), KR 56: 19 III 2008 (3), KR 103: 26 IV 2008 (5), KR 104: 19 III 2008 (12), KR 106: 19 III 2008 (9), KR 108: 7 V 2010 (2), KR 110: 26 IV 2012 (16), KR 156: 26 IV 2008 (1), KR 160: 17 IX 2009 (1), KR 217: 19 V 2010 (2), KR 400: 7 V 2010 (1), LA24: 16 III 2002 (3), LA154: 25 IV 1993 (2), Lipków: 26 IV 1982 (17), Łazy Leśne: 11 IV 2012 (3), Mlociny Park: 25 V 1983 (3), Mlynisko: 25 V 1983 (7), Na Miny: 3 X 2011 (84), Nart: 2 III 1984 (41), Palmiry-Lomna: 18 VII 1984 (4), Pociecha: 7 III 2012 (3), Posada Demboskie: 4 VIII 1989 (8), Radiowo: 30 VIII 1992 (2), Roztoka: 10 I 2012 (7), Sowia Wola Folwarczna: 27 VI 1996 (49), Wywrotnia Góra: 18 X 1994 (17), Zaborów Leśny: 25 IV 1982 (3), Zamczysko: 2 III 1984 (5), Żurawiowe: 6 IV 2005 (1).

\section{Water vole - Arvicola amphibius (Linnaeus, 1758)}

16 localities: Brzozówka N: 3 IV 2012 (1), Cyganka: 12 III 2012 (1), Dąb Kobendzy: 16 III 2012 (1), Grabowy Grąd: 22 VI 1982 (5), Izabelin: 2 V 2012 (1), KA 83: IV 2003 (1), Kaliszki: 8 XI 2011 (1), Korfowe: 12 VII 1999 (2), Ławy: 3 VI 2012 (2), Łazy Leśne: 11 IV 2012 (2), Mlynisko: 25 V 1983 (1), Na Miny: 3 X 2011 (2), Palmiry-Łomna: 18 VII 1984 (1), Posada Demboskie: 31 III 2000 (2), Roztoka: 12 IX 2012 (1), Stara Dąbrowa: 3 V 2012 (1).

\section{European pine vole - Microtus subterraneus (de Sélys-Longchamps, 1836)}

10 localities: Bemowo: 9 X 1998 (1), Dąb Kobendzy: 19 IV 1983 (3), KA 251: 30 III 2007 (6), KR 160: 26 IV 2012 (1), Krzywa Góra: X 2005 (2), Młociny Park: 25 V 1983 (1), Posada Demboskie: 31 III 2000 (4), Roztoka: VI 2010 (1), Wywrotnia Góra: III 2003 (1), Zaborów Leśny: 27 V 1995 (1).

\section{Common vole - Microtus arvalis (Pallas, 1779)}

28 localities: Aleksandrów: VI 2008 (2), Brzozówka N: 1 V 2012 (1), Dziekanów Leśny: 23 III 1982 (3), Grabowy Grąd: 22 VI 1982 (2), Izabelin: 2 V 2012 (9), KA 83: IV 2003 (2), KA 251: 30 III 2007 (1), Kaliszki: 18 VII 1984 (2), Korfowe: 12 VII 1999 (11), KR 20: 6 X 2011 (2), KR 56: 19 III 2008 (1), KR 103: 17 IX 2009 (1), KR 104: 19 III 2008 (1), KR 106: 4 V 2011 (4), KR 160: 7 V 2010 (1), KR 217: 6 X 2011 (1), KR 400: 7 V 2010 (1), Lipków: 26 IV 1982 (8), Młociny Park: 25 V 1983 (2), Młynisko: 22 VI 1983 (3), Nart: 2 III 1984 (2), Palmiry-Łomna: 18 VII 1984 (6), Posada Demboskie: 4 VIII 1989 (3), Radiowo 30 VIII 1992 (1), Roztoka: 12 IX 2012 (3), Sowia Wola Folwarczna: 7 IV 1994 (9), Wywrotnia Góra: 18 X 1994 (5), Zaborów Leśny: 25 IV 1982 (15).

Field vole - Microtus agrestis (Linnaeus, 1761)

24 localities: Cyganka: 12 III 2012 (2), Dąb Kobendzy: 6 X 2007 (2), Dziekanów Leśny: 23 III 1982 (2), Grabowy Grąd: 22 VI 1982 (4), KA 83: IV 2003 (1), KA 251: 10 III 1983 (3), Kaliszki: 18 VII 1984 (3), Korfowe: 12 VII 1999 (8), KR 56: 6 X 2011 (1), KR 104: 4 V 2011 (2), KR 106: 4 V 2011 (1), KR 110: 26 IV 2012 (6), KR 156: 17 IX 2009 (1), LA 154: 25 IV 1993 (1), Łazy Leśne: 11 IV 2012 (3), Mlynisko: 25 V 1983 (1), Na Miny: 3 X 2011 (56), Nart: 2 
G. Lesiński et al.

III 1984 (11), Pociecha: 7 III 2012 (1), Posada Demboskie: 12 X 1995 (1), Sowia Wola Folwarczna: 27 VI 1996 (4), Wywrotnia Góra: 26 II 1995 (3), Zaborów Leśny: 25 IV 1982 (1), Zamczysko: 2 III 1984 (1).

\section{Root vole - Microtus oeconomus (Pallas, 1776)}

32 localities: Brzozówka N: 1 V 2012 (1), Cyganka: 12 III 2012 (4), Dąb Kobendzy: 7 VIII 1994 (1), Dziekanów Leśny: 12 IV 1984 (6), Grabowy Grąd: 20 I 1982 (3), Izabelin: 2 V 2012 (13), KA 66: 10 II 2000 (12), KA 83: IV 2003 (1), KA 240: 10 III 1999 (2), KA 251: 10 III 1983 (1), Kaliszki: 18 VII 1984 (1), Korfowe: 12 VII 1999 (19), KR 103: 4 V 2011 (1), KR 106: 23 IV 2009 (1), KR 108: 26 IV 2008 (1), KR 156: 17 IX 2009 (1), KR 160: 4 V 2011 (3), KR 217: 6 X 2011 (2), LA 154: 25 IV 1993 (1), Lipków: 26 IV 1982 (3), Lazy Leśne: 11 IV 2012 (6), Mlociny Park: 25 V 1983 (1), Mlynisko: 25 V 1983 (2), Na Miny: 3 X 2011 (2), Nart: 2 III 1984 (4), Posada Demboskie: 4 VIII 1989 (3), Roztoka: 10 I 2012 (4), Sowia Wola: 13 VII 2012 (1), Sowia Wola Folwarczna: 7 IV 1994 (3), Wywrotnia Góra: 18 X 1994 (4), Zaborów Leśny: 25 IV 1982 (16), Żurawiowe: 6 IV 2005 (1).

\section{Western house mouse - Mus musculus Linnaeus, 1758}

19 localities: Aleksandrów: VI 2008 (1), Brzozówka N: 4 XI 2012 (1), Cyganka: 12 III 2012 (1), Dziekanów Leśny: 12 IV 1984 (4), Izabelin: 2 V 2012 (8), KA 83: 7 IV 2005 (1), Kaliszki: 18 VII 1984 (2), Korfowe: 12 VII 1999 (13), KR 20: 6 X 2011 (6), KR 104: 6 X 2011 (1), KR 106: 23 IV 2009 (1), Lipków: 26 IV 1982 (1), Młynisko: 25 V 1983 (1), Na Miny: 3 X 2011 (1), Posada Demboskie: 19 II 1990 (1), Radiowo: 30 VIII 1992 (1), Roztoka: 10 I 2012 (1), Sowia Wola Folwarczna: 7 IV 1994 (1), Zaborów Leśny: 23 II 1984 (3).

\section{Brown rat - Rattus norvegicus (Berkenhout, 1769)}

13 localities: Dziekanów Leśny: 20 VI 2000 (1), Grabowy Grąd: 22 VI 1982 (1), Izabelin: 2 V 2012 (1), KA 83: IV 2003 (1), KA 251: 30 III 2007 (1), Kaliszki: 18 IX 2012 (1), KR 106: 4 V 2011 (1), KR 160: 4 V 2011 (2), Lipków: 26 IV 1982 (1), Młociny Park: 28 III 2008 (1), Posada Demboskie: 4 VIII 1989 (2), Roztoka: 10 I 2012 (1), Sowia Wola Folwarczna: 27 VI 1996 (9).

\section{Striped field mouse - Apodemus agrarius (Pallas, 1771)}

25 localities: Aleksandrów: VI 2008 (1), Bemowo: 9 X 1998 (1), Brzozówka N: 31 XII 2012 (6), Dąb Kobendzy: 7 VIII 1994 (1), Dziekanów Leśny: 23 III 1982 (1), Grabowy Grąd: V 1983 (1), Izabelin: 2 V 2012 (3), KA 66: 10 II 2000 (1), KA 83: 7 IV 2005 (2), KA 251: 30 III 2007 (7), Kaliszki: 8 XI 2011 (2), Korfowe: 12 VII 1999 (4), KR 20: 4 V 2011 (15), KR 106: 23 IV 2009 (1), KR 108: 4 V 2011 (1), KR 156: 4 V 2011 (2), KR 160: 4 V 2011 (2), Lipków: 11 II 1983 (3), Młociny Park: 9 II 1984 (7), Młynisko: 25 V 1983 (1), Posada Demboskie: 3 VI 1996 (1), Radiowo: 30 VIII 1992 (1), Sowia Wola Folwarczna: 27 VI 1996 (20), Wywrotnia Góra: III 2003 (1), Zaborów Leśny: 23 II 1984 (1).

\section{Wood mouse - Apodemus sylvaticus (Linnaeus, 1758)}

21 localities: Brzozówka E: X 2006 (1), Dąb Kobendzy: 7 VIII 1994 (2), Dziekanów Leśny: 23 III 1982 (1), Grabowy Grą: 28 IV 1983 (1), Hornówek: 14 IV 1994 (2), KA 79: 16 IV 1994 (1), KA 83: XI 2004 (1), KA 101: 16 III 1995 (1), Kaliszki: 18 VII 1984 (1), Korfowe: 12 VII 1999 (5), KR 48: 22 III 1991 (1), KR 108: 4 V 2011 (1), KR 156: 4 V 2011 (3), KR 160: 4 V 2011 (1), Lipków: 26 IV 1982 (2), Nart: 2 III 1984 (2), Palmiry-Łomna: 18 VII 1984 (3), Posada Demboskie: 4 VIII 1989 (3), Sowia Wola Folwarczna: 7 IV 1994 (1), Wywrotnia Góra: 18 X 1994 (5), Zaborów Leśny: 23 II 1984 (2). 
Yellow-necked mouse - Apodemus flavicollis (Melchior, 1834)

35 localities: Bialy Grad: 12 V 1983 (4), Brzozówka N: 4 XI 2012 (1), Cyganka: 12 III 2012 (5), Dab Kobendzy: 7 VIII 1994 (2), Dziekanów Leśny: 20 II 1984 (4), Grabowy Grad: 22 VI 1982 (1), Granica: VII 2004 (1), Izabelin: 7 VIII 2012 (3), KA 83: IV 2003 (2), KA 240: 10 III 1999 (3), Kaliszki: 8 XI 2011 (4), Korfowe: 12 VII 1999 (20), KR 20: 6 X 2011 (1), KR 56: 6 X 2011 (2), KR 103: 6 X 2011 (4), KR 104: 7 V 2010 (2), KR 106: 19 III 2008 (1), KR 108: 4 V 2011 (3), KR 110: 26 IV 2012 (3), KR 156: 26 IV 2008 (1), KR 160: 4 V 2011 (1), KR 217: 19 V 2010 (1), Lipków: 11 II 1983 (1), Lazy Leśne: 11 IV 2012 (3), Młociny Park: 25 V 1983 (2), Mlynisko: 25 V 1983 (2), Na Miny: 3 X 2011 (22), Nart: 2 III 1984 (8), Palmiry-Lomna: 18 VII 1984 (3), Pociecha: 7 III 2012 (1), Posada Demboskie: 4 VIII 1989 (5), Roztoka: 10 I 2012 (2), Sowia Wola Folwarczna: 7 IV 1994 (1), Wywrotnia Góra: 18 X 1994 (5), Zaborów Leśny: 13 VIII 1980 (1).

\section{Harvest mouse - Micromys minutus (Pallas, 1771)}

29 localities: Brzozówka N: 10 III 2012 (6), Cyganka: 12 III 2012 (1), Dąb Kobendzy: 16 III 2012 (2), Dziekanów Leśny: 23 III 1982 (2), Grabowy Grad: I 1983 (2), Izabelin: 2 V 2012 (7), KA 66: 10 II 2000 (4), KA 83: 4 V 2011 (8), KA 251: 30 III 2007 (5), Kaliszki: 8 XI 2011 (1), Korfowe: 12 VII 1999 (11), KR 4: 13 IV 2012 (2), KR 103: 26 IV 2012 (1), KR 104: 19 III 2008 (2), KR 106: 23 IV 2009 (2), KR 108: 4 V 2011 (1), KR 110: 26 IV 2012 (3), KR 156: 23 IV 2009 (1), KR 160: 4 V 2011 (1), Lipków: 26 IV 1982 (1), Lawy: 5 IV 2012 (1), Mlociny Park: 9 II 1984 (2), Mlynisko: 22 VI 1983 (2), Na Miny: 3 X 2011 (7), Posada Demboskie: 19 II 1990 (1), Roztoka: VI 2010 (2), Sowia Wola Folwarczna: 27 VI 1996 (46), Wywrotnia Góra: 18 X 1994 (1), Zaborów Leśny: 27 V 1995 (16).

\section{Common dormouse - Muscardinus avellanarius (Linnaeus, 1758)}

20 localities: Bialy Grąd: 12 V 1983 (1), Cyganka: 12 III 2012 (5), Dziekanów Leśny: 20 VI 2000 (1), Grabowy Grad: V 1983 (1), KA 83: IV 2003 (5), Kaliszki: 18 IX 2012 (1), Korfowe: 12 VII 1999 (5), KR 103: 4 V 2011 (2), KR 104: 23 IV 2009 (1), KR 106: 23 IV 2009 (1), KR 108: 4 V 2011 (2), KR 156: 23 IV 2009 (1), KR 160: 4 V 2011 (1), Mlynisko: 25 V 1983 (1), Na Miny: 3 X 2011 (8), Posada Demboskie: 28 IV 1992 (1), Roztoka: 10 I 2012 (2), Sowia Wola Folwarczna: 7 IV 1994 (2), Wywrotnia Góra: 18 X 1994 (5), Zaborów Leśny: 13 VIII 1980 (1).

\section{Red squirrel - Sciurus vulgaris Linnaeus, 1758}

2 localities: Dąb Kobendzy: 6 X 2007 (1), Posada Demboskie: IV 2006 (1).

Myodes glareolus was the most common and a relatively abundant species in the rodent communities throughout the study area (48 localities), followed by Apodemus flavicollis ( 35 localities) and Microtus oeconomus (32 localities). Among the rodents connected to wet habitats, Microtus oeconomus was noted frequently, whereas Arvicola amphibius appeared to be rare (Fig. 3) (highest share in the owls' diet: 1.8\% of mammals - Grabowy Grad, N=448). In the group of rodents typical of open areas, Microtus arvalis was the most frequent (28 localities) and abundant. The most frequent presence of Muscardinus avellanarius (Fig. 4), a species typical of broad-leaved tree stands, including wet forests with alders, was close to the strictly protected areas. $M$. avellanarius was relatively frequently captured in Cyganka $-5.0 \%$ $(\mathrm{N}=119)$, Wywrotnia Góra - 4.4\% $(\mathrm{N}=113)$, KA 83 - 4.0\% ( $=273)$ and Sowia Wola Folwarczna $-3.5 \%(\mathrm{~N}=1,271)$. Another arboreal rodent (Sciurus vulgaris) was an extremely rare prey of the examined owls, and synanthropic rodents (Mus musculus and Rattus norvegicus) occurred in low numbers in various parts of Kampinos Forest. Microtus subterraneus was very rarely captured by owls, except for the eastern edges of the study area where it was relatively abundant at some sites (e.g., Mlociny Park). 


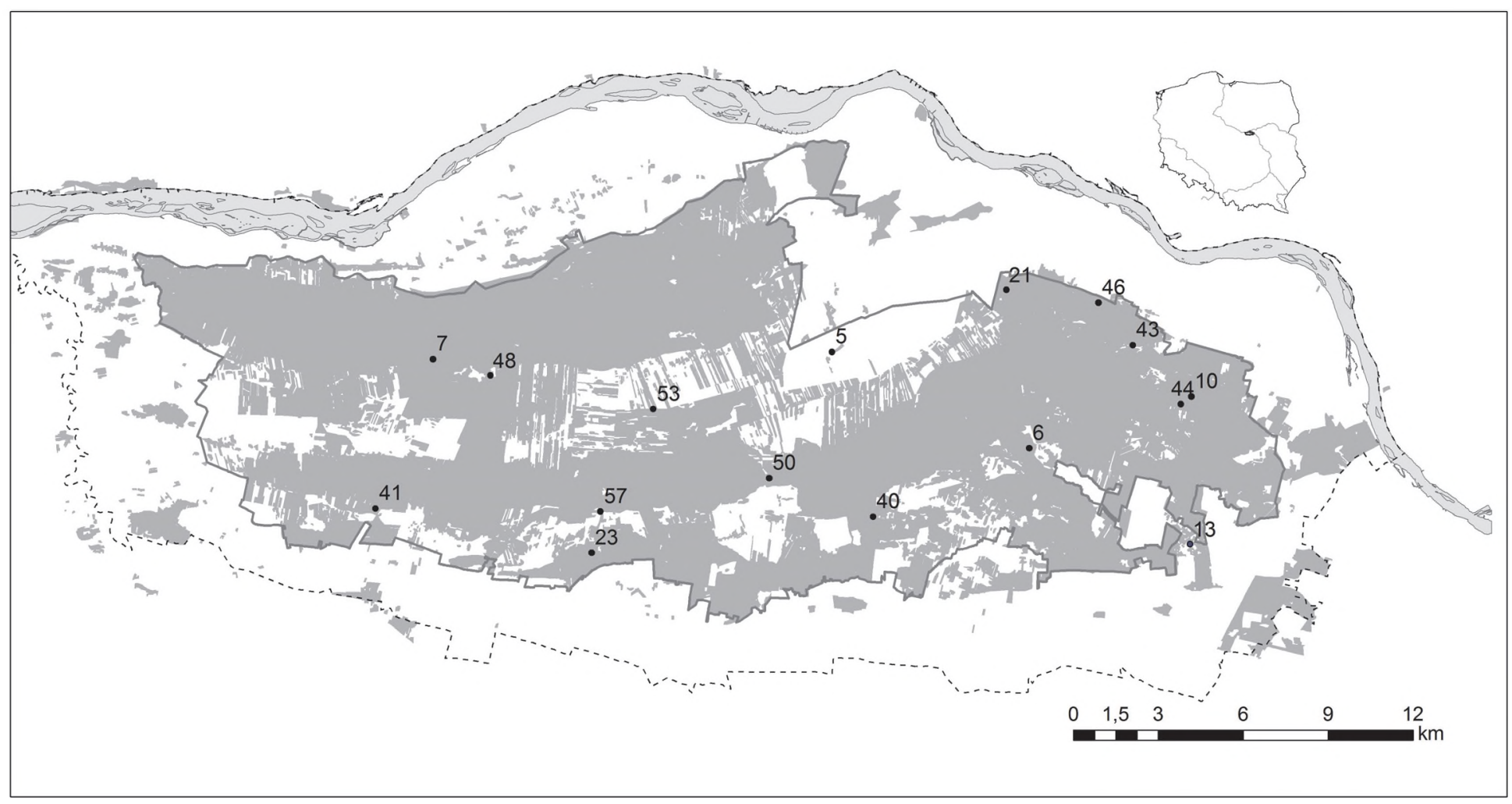

Fig. 3. Localities of Arvicola amphibius in the study area. For explanations see Fig. 1. 


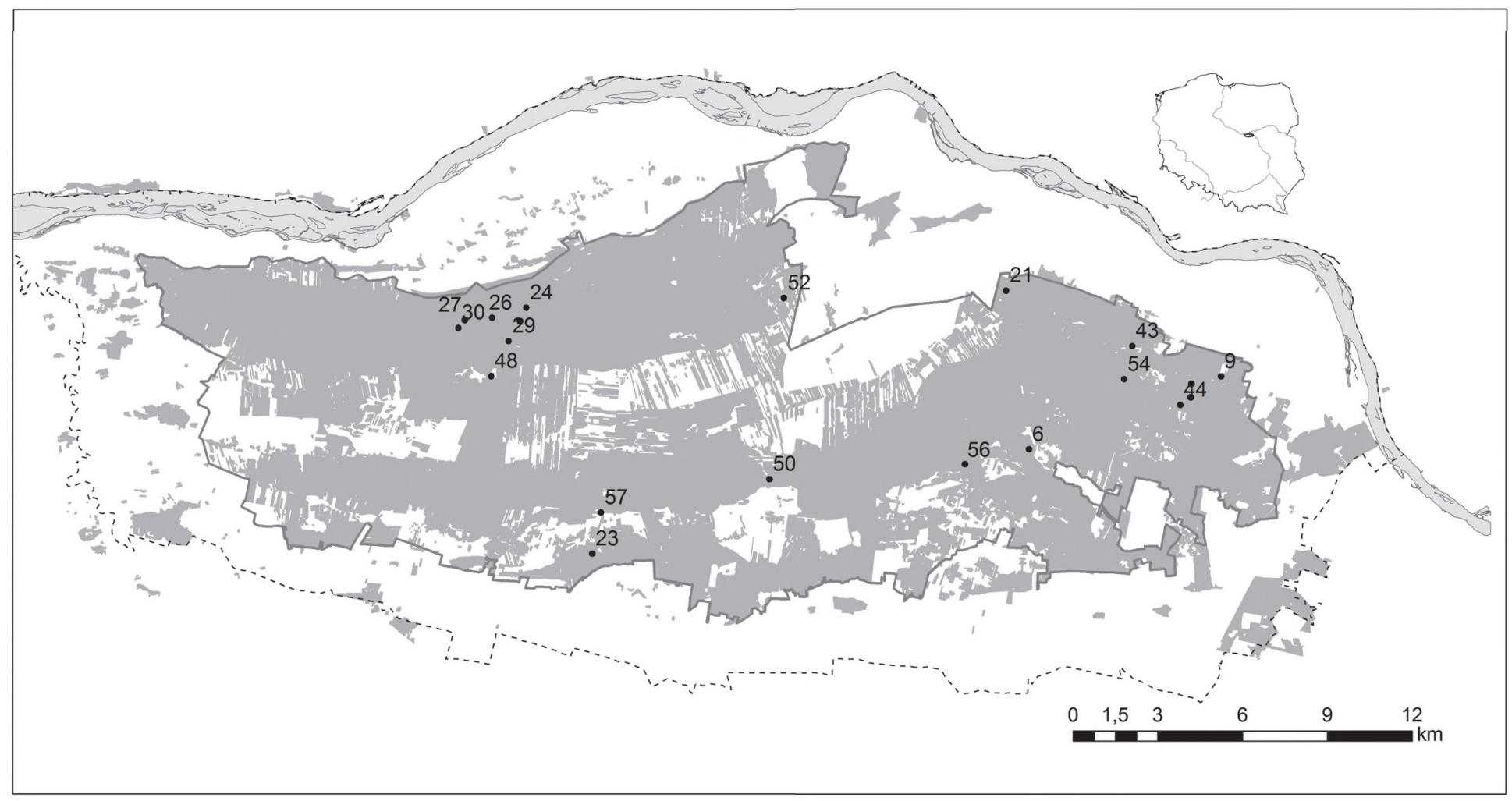

Fig. 4. Localities of Muscardinus avellanarius in the study area. For explanations see Fig. 1. 
Lagomorpha

Brown hare - Lepus europaeus Linnaeus, 1758

2 localities: Korfowe: 12 VII 1999 (1), Sowia Wola Folwarczna: 15 IV 1994 (1).

This order was only sporadically represented in the diet of tawny owls in the study area. Only young individuals were captured individually.

\section{Carnivora}

\section{Weasel - Mustela nivalis Linnaeus, 1766}

4 localities: KR 156: 17 IX 2009 (1), Młociny Park: 14 IV 2012 (1), Na Miny: 3 X 2011 (1), Sowia Wola Folwarczna: 7 IV 1994 (1).

A species from the family Mustelidae was an accidental owl prey. Only four localities from different parts of the study area were represented.

The most common and abundant in the total analysed material of owl pellets were: Myodes glareolus, Sorex araneus, Apodemus flavicollis and Sorex minutus. Some species connected to open areas (Microtus arvalis, M. oeconomus) or waters (Neomys fodiens) were also captured relatively frequently (Fig. 5).

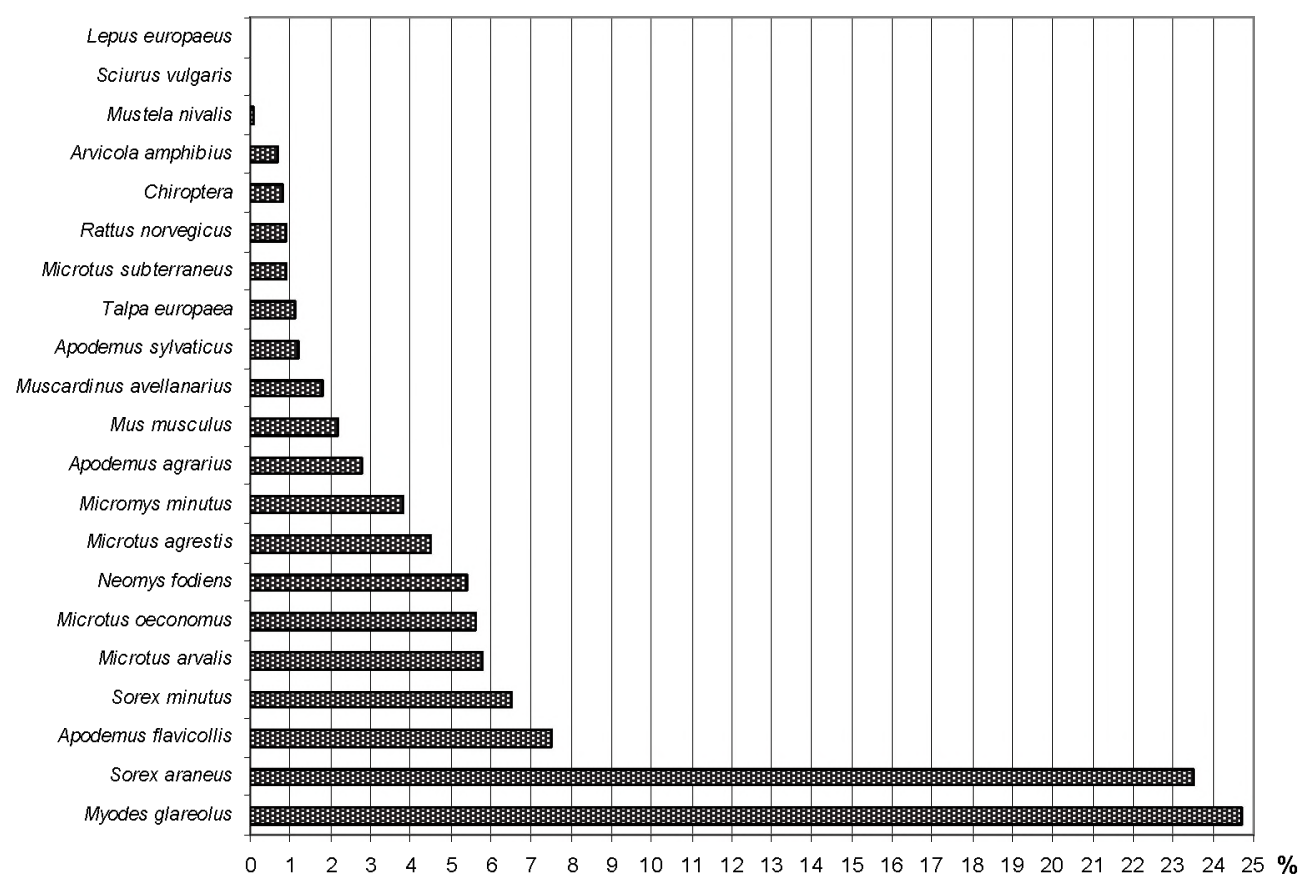

Fig. 5. Percentage of species or groups of species in the food of tawny owls in the study area. Only individuals identified to the species level $(7,522)$ were considered in the analysis. 


\section{DISCUSSION}

Compared to the results of previous work (Goszczyński et al. 1993, Andrzejewski 2003, Lesiński 2003, Lesiński et al. 2011, Danylow et al. 2012), there were no new species recorded in the present study. Nevertheless, the data shown provide more precise information on the proportion of species in the community and the distribution of their localities.

Kampinos Forest in central Poland offers suitable habitats for diverse communities of small mammals, though the species richness does not differ distinctly, even compared to more fragmented forests. In the smaller forests within the vicinity of Łódź, only one species of rodents, Muscardinus avellanarius, was absent (Gryz et al. 2011).

The distribution of Muscardinus avellanarius in Kampinos Forest was related to the presence of wet forest, which occurs frequently, covering large areas in some places. Most likely, these areas represent an important refuge of this species on the border of its continuous range in Poland. $M$. avellanarius was reported in single, isolated localities in areas situated in the north and north-west (Pucek 1983, Neubauer \& Zagalska-Neubauer 2003) and was absent in several owl diet studies (Kowalski 1961, Kowalski \& Lesiński 1986, 1988, Lesiński \& Gryz 2008). This arboreal rodent is the only representative of the family Gliridae in Kampinos Forest. The nearest localities of edible dormouse Glis glis (Linnaeus, 1866) were found approx. $100 \mathrm{~km}$ southeast (Kozienice Forest - Kurowski 1997). Therefore, the presence of this species in Kampinos Forest is not likely.

The study area offers suitable habitats for small mammals that are associated with water bodies or marshes. Microtus oeconomus and, to a lesser degree, Neomys fodiens appear to be relatively common and locally abundant. Arvicola amphibius was less frequently captured by owls and was not abundant. Compared to some samples of tawny owl diets from southern Poland, sites where it was one of the most important prey (Bocheński jun. 1990, Ruprecht 2002, Lesiński \& Stolarz 2012), we could presume that $A$. amphibius in Kampinos Forest is not abundant.

Our study confirmed the absence of the northern birch mouse Sicista betulina (Pallas, 1778) in Kampinos Forest, though the closest locality of this rodent is known approx. $30 \mathrm{~km}$ east - in Okuniew-Rembertów Forest (Lesiński et al. 1998). Most of the wet forests in the study area might be unsuitable for this species.

It is possible that some small mammals, particularly bats, might still be found in Kampinos Forest. To date, 15 species comprise the bat fauna of this area (Lesiński 2003). The northern bat Eptesicus nilssonii (Keyserling \& Blasius, 1839) was recorded in Warsaw (Lesiński et al. 2001) and in the vicinity of Naruszewo (Lesiński et al. 2008) (8 and $12 \mathrm{~km}$ from the study area, respectively). The common pipistrelle Pipistrellus pipistrellus (Schreber, 1774) and Bechstein's bat Myotis bechsteinii (Kuhl, 1817) are also possible. The former is known in many regions of Poland, though it is rare in the central and eastern part (Sachanowicz et al. 2006). Despite its continuous range being limited to areas situated approx. $50 \mathrm{~km}$ south (Ciechanowski \& Piksa 2004), a locality of $M$. bechsteinii was found north of the study area in Strubiny fort near Modlin (Fuszara \& Kowalski 2009). Moreover, bat species only occasionally found in central Poland, such as the giant noctule Nyctalus lasiopterus (Schreber, 1780) (Ruprecht 1970) or Kuhl's pipistrelle Pipistrellus kuhlii (Kuhl, 1817) (Popczyk et al. 2008), can not be excluded.

Bats are considered to be highly endangered by human activity. Two of the species found in the tawny owl pellet samples from Kampinos Forest (Myotis myotis and Barbastella barbastellus) were included in the $2^{\text {nd }}$ Annex to the Habitats Directive of the European Union. Moreover, one species (Vespertilio murinus) was mentioned in the Polish Red Data Book under the category 'least concerned' (LC) (Glowaciński 2001). 
With regard to Soricomorpha and Rodentia, all possible small species have most likely been identified. The continuous range of the bicolour white-toothed shrew Crocidura leucodon (Hermann, 1780) is rather distant from the study area (Pucek \& Michalak 1983). Sciurus vulgaris is the largest rodent prey. The northern white-breasted hedgehog Erinaceus roumanicus BarrettHamilton, 1900 is only rarely captured by tawny owls (Gryz et al. 2008) as are carnivores larger than Mustela nivalis (Korpimäki \& Norrdahl 1989, Gryz et al. 2008). Within Carnivora, the American mink Neovison vison Schreber, 1777 and stoat Mustela erminea Linnaeus, 1758 were found in the tawny owl pellets. No rabbits Oryctolagus cuniculus (Linnaeus, 1758) were found in our material, however, this species was recorded in Torun (Zalewski 1994). Species representing the order Lagomorpha are extremely rare prey for tawny owls.

There was a relatively high proportion of synanthropic rodents (Mus musculus and Rattus norvegicus) and water-connected rodents (Arvicola amphibius and Neomys fodiens) in the diet of the tawny owls in Kampinos Forest compared to some forests of north-eastern Poland: Bialowieża Forest, Romincka Forest, Augustów Forest, Forests of Biebrza National Park and Knyszyn Forest. However, Apodemus flavicollis - an important prey item, particularly in Bialowieża and Knyszyn Forests - occurred in lower proportions in the study area. In all the mentioned forests, Myodes glareolus was abundantly captured by tawny owls. Bats were recorded relatively frequently in Kampinos Forest, and their proportion in owl diets was higher only in Knyszyn Forest (Table 1). This finding most likely results from the fact that our study area is a mosaic of different habitats, both only slightly and highly transformed by human activity.

Table 1. Proportions of selected mammal taxa in the diets of the tawny owl from the study area and several forests of northeastern Poland; (1) - this study, N=7,522; (2) - after Table 1 in Jedrzejewski et al. (1994), N=2,603; (3) - Gryz et al. 2012, N=309 (only forest habitats); (4) - Lesiński et al. 2009, N=147; (5) - Lesiński et al. 2009, Gryz et al. 2011, $\mathrm{N}=1,669$; (6) - Zawadzka \& Zawadzki 2007, N=543; (7) - Żmihorski \& Osojca 2006, N=245; N - number of mammalian prey items.

\begin{tabular}{|l|c|c|c|c|c|c|c|}
\hline \multicolumn{1}{|c|}{ Taxon } & $\begin{array}{c}\text { Kampinos } \\
\text { Forest } \\
(1)\end{array}$ & $\begin{array}{c}\text { Białowieża } \\
\text { Forest } \\
(2)\end{array}$ & $\begin{array}{c}\text { Białowieża } \\
\text { Forest } \\
(3)\end{array}$ & $\begin{array}{c}\text { Knyszyn } \\
\text { Forest } \\
(4)\end{array}$ & $\begin{array}{c}\text { Forests of Biebrza } \\
\text { National Park } \\
(5)\end{array}$ & $\begin{array}{c}\text { Augustów } \\
\text { Forest } \\
(6)\end{array}$ & $\begin{array}{c}\text { Romincka } \\
\text { Forest } \\
(7)\end{array}$ \\
\hline Sorex araneus & 23.5 & 16.5 & 21.4 & 1.4 & 13.7 & 7.0 & 19.6 \\
\hline Neomys fodiens & 5.4 & 0.4 & 8.1 & 0 & 1.9 & 0.4 & 0 \\
\hline Chiroptera & 0.8 & 0 & 0 & 2.7 & 0.5 & 0 & 0 \\
\hline Arvicola amphibius & 0.7 & no data* & 0.3 & 0 & 0.7 & 0 & 0 \\
\hline Myodes glareolus & 24.7 & 34.6 & 20.7 & 19.0 & 30.5 & 16.6 & 27.8 \\
\hline Microtus oeconomus & 5.6 & 6.5 & 1.9 & 0 & 8.5 & 4.2 & 1.2 \\
\hline Microtus agrestis & 4.5 & 1.0 & 4.9 & 3.4 & 3.9 & 3.1 & 1.2 \\
\hline Apodemus flavicollis & 7.5 & 28.5 & 17.8 & 42.9 & 7.8 & 3.9 & $8.2 * *$ \\
\hline $\begin{array}{l}\text { Mus musculus \& Rattus } \\
\text { norvegicus }\end{array}$ & 3.1 & no data & 0.3 & 0.7 & 2.8 & 3.7 & 0 \\
\hline $\begin{array}{l}\text { Muscardinus } \\
\text { avellanarius }\end{array}$ & 1.8 & no data & 0 & 0 & & & \\
\hline
\end{tabular}

* $-0.2 \%$ calculated from Table 4 in Jędrzejewski et al. (1994);

* - Apodemus flavicollis and A. sylvaticus were not distinguished.

\section{ACKNOWLEDGEMENTS}

We are grateful to Jakub Paweł Cygan, Marcin Dziedzic, Maciej Fuszara, Andżelika Haidt, Tomasz Hryniewicki, Nina Kłos, Dawid Marczak, Agnieszka Nowak, Grzegorz Okolów, Kazimierz Sierakowski, Anna Siwak, Tomasz Sulej, Piotr Szpakowski, Joanna Wachowicz and Michal Żmihorski for their help in collecting pellets, and Jacek Kozlowski for technical support. 


\section{REFERENCES}

ADAMCZYK K., CHEEKOWSKA H. \& WALKOWA W. 1988. The community of rodents in environments of the suburban zone. Polish Ecological Studies 14: 171-195.

ANDRZEJEWSKA A., LENARTOWICZ M. \& SOMOROWSKA U. 2012. Kampinoski Park Narodowy. In: BogDANOWICZ R., JokIEL P. \& POCIASK-KARTECZKA J. (eds), Wody w parkach narodowych Polski. Instytut Geografii i Gospodarki Przestrzennej - Uniwersytet Jagielloński, Komisja Hydrologiczna - Polskie Towarzystwo Geograficzne, Kraków: 106-119.

ANDRZEJEWSKA A., FERCHMIN M., KĘBEOWSKA A. \& OTREBAA A. 2010. Charakterystyka geobotaniczna Puszczy Kampinoskiej. In: OBIDZnj́ski A. (ed.), Z Mazowsza na Polesie i Wileńszczyznę. Zróżnicowanie i ochrona szaty roślinnej pogranicza Europy Środkowej i Pólnocno-Wschodniej. Monografia sesji terenowych LV Zjazdu Polskiego Towarzystwa Botanicznego 'Planta in vivo, in vitro et in silico'. Warszawa, 6-12.09.2010, pp. 41-56. Polskie Towarzystwo Botaniczne - Zarząd Glówny, Warszawa.

ANDRZEJEWSKI R. 2003. Drobne ssaki owadożerne i gryzonie. In: ANDRZEJEWSKI R. (ed.), Kampinoski Park Narodowy, vol. 1, pp. 655-662. Kampinoski Park Narodowy, Izabelin.

ANDRZEJEWSKI R., BABIŃSKA-WERKA J., GLIWICZ J. \& GOSZCZYISSKI J. 1978. Synurbization processes in population of Apodemus agrarius. I. Characteristics of population in urbanization gradient. Acta Theriologica 23: 341-358.

BOCHEŃSKI Z. jun. 1990. The food of suburban Tawny Owls on the background of birds and mammals occurring in the hunting territory. Acta Zoologica Cracoviensia 33: 149-171.

CIECHANowsKi M. \& PIKSA K. 2004. Myotis bechsteinii (Kuhl, 1819). In: ADAMSKI P., BARTEL R., BERESZYŃsKI A., KEPEL A., WITKOWSKi Z. (eds) Poradniki ochrony siedlisk i gatunków Natura 2000 - podręcznik metodyczny. Vol. 6. Gatunki zwierząt (z wyjątkiem ptaków), pp. 357-362. Ministerstwo Srodowiska, Warszawa.

Danylow J., Figat E., Jeziorski J., MARczaK D., Olech B., Olszewski A., OKolów G., PePlowska-Marczak D. \& SIWAK A. 2012. Operat Ochrony Fauny. Biblioteka Kampinoskiego Parku Narodowego, Izabelin, 126 pp.

FUSZARA M. \& KOWALSKI M. 2009. Nocek Bechsteina Myotis bechsteinii (Kuhl, 1817) podczas jesiennego rojenia w fortach modlińskich. Nietoperze 10: 81-83.

Glowaciński Z. (ed.) 2001. Polska Czerwona Księga Zwierząt. Kręgowce. PWRiL, Warszawa, 452 pp.

GOSZCZYNSKI J., JABŁoNSKI P., LESINSKI G. \& ROMANOWSKI J. 1993. Variation in diet of Tawny Owl Strix aluco L. along an urbanization gradient. Acta Ornithologica 27: 113-123.

GRYZ J., GÓŹDŹ I. \& KRAUZE-GRYZ D. 2011. Wpływ antropogenicznego przekształcenia krajobrazu na skład pokarmu puszczyka Strix aluco L. w Biebrzańskim Parku Narodowym. Parki Narodowe i Rezerwaty Przyrody 30 (3/4): 109-118.

GRYZ J., KRAUZE D. \& GoszCZYŃSKI J. 2008. The small mammals of Warsaw as inferred from tawny owl (Strix aluco) pellet analyses. Annales Zoologici Fennici 45: 281-285.

GRYZ J., KRAUZE-GRyz D. \& LESIŃsKi G. 2011. Mammals in the vicinity of Rogów (central Poland). Fragmenta Faunistica 54: 183-197.

GRYZ J., LESIŃSKi G., KOWALSKi M. \& KRAUZE D. 2012. Skład pokarmu puszezyka Strix aluco w Puszezy Białowieskiej. Chrońmy Przyrodę Ojczystą 68 (2): 100-108.

JEDRZEJEWSKI W., JĘDRZEJEWSKA B., ZUB K., RUPRECHT A. L. \& BystRowski C. 1994. Resource use by Tawny Owls Strix aluco in relation to rodent fluctuations in Bialowieża National Park, Poland. Journal of Avian Biology 25: 308-318.

KORPIMÄKI E. \& NORRDAHL K. 1989. Avian predation on mustelids in Europe 1: occurrence and effects on body size variation and life traits. Oikos 55: 205-215.

KOWALSKI K. 1961. Materiały do znajomości fauny ssaków Puszczy Piskiej. Acta Theriologica 4: 295-296.

KOWALSKI M. \& LESIŃSKI G. 1986. Fauna drobnych ssaków w Janowie (woj. stoleczne) na podstawie analizy zrzutek płomykówki (Tyto alba Scop.). Przegląd Zoologiczny 30: 327-331.

KowALSKI M. \& LESIŃSKI G. 1988. Drobne ssaki w pokarmie puszezyka Strix aluco znad jeziora Luknajno. Chrońmy Przyrodę Ojczystą 44 (4): 80-82.

KOWALSKI M. \& LESIŃSKI G. 1995. Skład gatunkowy i wybiórczość kryjówek nietoperzy w Puszczy Kampinoskiej. Przegląd Przyrodniczy 6 (2): 99-108.

KURowski M. 1997. Fauna. In: ZIELONY R. (ed.), Lasy Puszczy Kozienickiej. Monografia przyrodniczoleśna. Wydawnictwo SGGW, Warszawa: 122-132.

LESIŃSKI G. 2003. Nietoperze. In: ANDRZEJEWSKi R. (ed.) Kampinoski Park Narodowy, vol. 1. Kampinoski Park Narodowy, Izabelin: 647-654.

LESIŃSKI G., BLICHARSKI M. \& SIELECKI M. 1998. Stanowisko smużki Sicista betulina koło Warszawy. Kulon 3 : 101-103.

LESIŃSKI G., BŁACHOWSKI G. \& SIUCHNO M. 2009. Vertebrates in the diet of the tawny owl Strix aluco in northern Podlasie (NE Poland) - comparison of forest and rural habitats. Fragmenta Faunistica 52: 51-59.

Lesiński G., Fuszara E., Fuszara M., POPCZYK B. \& RuPRECHT A. L. 2008. The occurrence of the northern bat Eptesicus nilssonii (Keyserling et Blasius, 1839) in Warsaw and its vicinity, Central Poland. Nyctalus (N.F.) 13: $137-141$. 
LESIŃSKI G., FUSZARA E. \& KOWALSKI M. 2001. Charakterystyka miejskiego zgrupowania nietoperzy Warszawy. Nietoperze 2: 3-17.

LESINSKI G. \& GRYZ J. 2008. Localities of three rare mammal species in central and northeastern Poland. Fragmenta Faunistica 51: 63-69.

LESIŃSKI G. \& GRYZ J. 2012. How protecting a suburban forest as a natural reserve effected small mammal communities. Urban Ecosystems 15: 103-110.

LESIŃSKI G., MACKIN-ROGALSKA R., PINOWSKI J. \& ROMANOWSKI J. 1990. Wpływ strefy podmiejskiej Warszawy na rozmieszczenie i liczebność ptaków i drobnych ssaków. In: Biernacki et al. (eds), Środowisko przyrodnicze Warszawy, pp. 587-599. PWN, Warszawa.

LESIŃSKI G., OLSZEWSKI A. \& POPCZYK B. 2011. Forest roads used by commuting and foraging bats in edge and interior zones. Polish Journal of Ecology 59: 611-616.

LESIŃSKI G. \& STOLARZ P. 2012. Drobne ssaki w Paszkówce koło Krakowa na podstawie analizy zrzutek puszczyka Strix aluco. Chrońmy Przyrodẹ Ojczysta 68 (2): 109-113.

LOPUCKI R., MRóz I. \& PRASOWSKA M. 2007. Zmiany składu gatunkowego gryzoni na terenie olsów Kampinoskiego Parku Narodowego wywołane obniżaniem się poziomu wód gruntowych. Chrońmy Przyrodę Ojczystą 63 (1): $72-82$.

NeUBAUER G. \& ZAGALSKA-NEUBAUER M. 2003. Nowe stanowisko orzesznicy Muscardinus avellanarius na Pojezierzu Chelmińskim. Przegląd Przyrodniczy 14 (1/2): 186-187.

POPCZYK B., LESIŃSKI G., BAUMANN A. \& WOJTOWICZ B. 2008. Kuhl's pipistrelle, Pipistrellus kuhlii (Kuhl, 1817) or Pipistrellus lepidus Blyth, 1845, in Central Poland - accidental record or a result of expansion? Nyctalus (N.F.) 13: $279-281$.

PUCEK Z. 1983. Muscardinus avellanarius Linnaeus, 1758. In: PUCEK Z., RACZYŃsKI J. (eds), Atlas of Polish mammals, pp. 137-138. PWN, Warszawa.

PUCEK Z. (ed.) 1984. Klucz do oznaczania ssaków Polski. PWN, Warszawa.

PUCEK Z. \& MiCHALAK I. 1983. Crocidura leucodon (Hermann, 1780). In: PUCEK Z., RACZYNiski J. (eds) Atlas of Polish mammals. PWN, Warszawa: 60-61.

ROMANOWSKI J. 1988. Trophic ecology of Asio otus (L.) and Athene noctua (Scop.) in the suburbs of Warsaw. Polish Ecological Studies 14: 223-234.

ROMANOWSKI J. \& ŻMIHORSKI M. 2006. Pokarm pójdźki Athene noctua w sezonie lęgowym z krajobrazu rolniczego Niziny Mazowieckiej. Notatki Ornitologiczne 47: 203-206.

ROMANOWSKI J. \& ŻMHORSKI M. 2008. Effect of season, weather and habitat on diet variation of a feeding specialist: a case study of the long-eared owl, Asio otus in Central Poland. Folia Zoologica 57: 411-419.

ROMANOWSKI J. \& ŻMTHORSKI M. 2009. Seasonal and habitat variation in the diet of the tawny owl (Strix aluco) in Central Poland during unusually warm years. Biologia 64: 365-369.

RUPRECHT A. L. 1970. Borowiec olbrzymi, Nyctalus lasiopterus (Schreber, 1780) - nowy ssak w faunie Polski. Acta Theriologica 15: 370-371.

RUPRECHT A. L. 1987. Klucz do oznaczania żuchw nietoperzy fauny Polski. Przegląd Zoologiczny 31: 89-105.

RUPRECHT A. L. 2002. Sklad pokarmu puszczyka zwyczajnego Strix aluco L. z Beskidu Wyspowego (Dobra k. Limanowej). Przegląd Przyrodniczy 13 (1/2): 191-197.

SACHANOWICZ K., CIECHANOWSKI M. \& PIKSA K. 2006. Distribution patterns, species richness and status of bats in Poland. Vespertilio 9/10: 151-173.

ZALEWSKI A. 1994. Diet of urban and suburban tawny owls (Strix aluco) in the breeding season. Journal of Raptor Research 28: 246-252.

ZAWADZKA D. \& ZAWADZKI J. 2007. Feeding ecology of Tawny Owl (Strix aluco) in Wigry National Park (North East Poland). Acta Zoologica Lituanica 17: 234-241.

ŻMாHORSKI M. 2005. Pokarm uszatki w krajobrazie rolniczym i leśnym. Notatki Ornitologiczne 46: 127-130.

ŻMHORSKI M. \& OsoJCA G. 2006. Diet of the Tawny Owl (Strix aluco) in the Romincka Forest (North East Poland). Acta Zoologica Lituanica 16: 54-60.

\section{STRESZCZENIE}

\section{[Drobne ssaki Kampinoskiego Parku Narodowego i jego otuliny wykazane w wyniku analizy diety puszczyków Strix aluco Linnaeus, 1758]}

W pracy analizowano zrzutki puszczyka Strix aluco w celu określenia składu gatunkowego, stanowisk i względnego zagęszczenia drobnych ssaków w Kampinoskim Parku Narodowym i jego otulinie (Fig. 1). Material zebrany na 58 stanowiskach zawieral szczątki 11235 ofiar kręgowych, wśród których znajdowało się 8335 ssaków. Wykryto 29 gatunków: ryjówkoksztaltne Soricomorpha - 4, nietoperze Chiroptera - 9, gryzonie Rodentia - 14, zajęczaki Lagomorpha - 1, drapieżne Carnivora - 1. W badanym materiale stwierdzono 
obecność trzech cennych gatunków nietoperzy: dwóch wymienionych w II Zalączniku Dyrektywy Siedliskowej Unii Europejskiej (nocka dużego Myotis myotis i mopka Barbastella barbastellus) oraz mroczka posrebrzanego Vespertilio murinus znajdującego się Polskiej Czerwonej Księdze Zwierząt (kategoria - „gatunek mniejszej troski” LC). Spośród gryzoni z rodziny popielicowatych Gliridae zanotowano obecność orzesznicy Muscardinus avellanarius, gatunku związanego $\mathrm{z}$ drzewostanami liściastymi, zwlaszcza olsami. W odpowiednich środowiskach jej udzial $w$ diecie puszczyka wynosił ok. 5\%. Stosunkowo często i licznie notowano niektóre gatunki związane ze środowiskami podmoklymi (nornika pólnocnego Microtus oeconomus i rzęsorka rzeczka Neomys fodiens), natomiast karczownik Arvicola amphibius był notowany rzadziej i mniej licznie (Fig. 5). Ważne ostoje bogatych zgrupowań drobnych ssaków zlokalizowano głównie na terenach objętych ochroną ścisłą. W porównaniu z kompleksami leśnymi zlokalizowanymi w pólnocno-wschodniej Polsce, Puszcza Kampinoska wyróżnia się stosunkowo dużym udziałem w diecie puszczyków takich ssaków, jak: nietoperze, gatunki związane ze środowiskiem podmokłym oraz gatunki synantropijne (Tab. 1). Przedstawione tu wyniki pozwolily na wykazanie prawdopodobnie pelnej listy drobnych ssaków z rzędów: ryjówkoksztaltne i gryzonie, podczas gdy możliwe jest jeszcze odnalezienie 3-5 gatunków nietoperzy i dwóch malych gatunków drapieżnych. 